\title{
Paulo Emílio e Os filmes na cidade (1966): a gênese da comédia musical ${ }^{1}$
}

Rafael Morato Zanatto ${ }^{2}$

${ }_{1}^{1}$ Apresentamos um panorama do curso Os filmes na cidade (1966) no XXII Encontro da Socine, realizado na Universidade Federal de Goiás (2018).

${ }^{2}$ Historiador, mestre e doutor em História pela UNESP - FCL Assis, com a tese Paulo Emílio e a Cultura Cinematográfica: crítica e história na formação do cinema brasileiro, 1940-1977 (2018), com amparo da FAPESP, instituição que financiou a pesquisa no Brasil e instituições estrangeiras como Cinémathèque Française (BEPE, 2012) e Deutsche Kinemathek (BEPE, 2017). Foi pesquisador e arquivista da Cinemateca Brasileira e atualmente desenvolve o projeto $A$ contribuição francesa e alemã à formação da história do cinema: critérios, teorias e perspectivas, 1945-1952 (FAPESP 2019/13106-8) na Escola de Comunicação e Artes ECA-USP, sob a supervisão do Prof. Dr. Eduardo Morettin.

Email: rafael zanatto@hotmail.com 


\section{Resumo}

No presente artigo, analisaremos parte completamente desconhecida da trajetória intelectual de Paulo Emílio Sales Gomes: os manuscritos do curso Os filmes na cidade (1966), elo perdido entre as pesquisas históricas que realizou sobre o cinema brasileiro, antes e depois do golpe civil-militar (1964). Aqui, veremos apenas como Paulo Emílio investiga nas manifestações culturais e nas fisionomias femininas no Rio de Janeiro do século XIX a gênese das comédias musicais, tomadas como o gênero de maior expressividade do cinema brasileiro. Remontando um mosaico de indicações de leitura e transcrições, veremos como a expressividade cultural da comédia musical é interpretada na perspectiva de uma história econômica, psicológica, social e cultural de longa duração.

Palavras-chave: Paulo Emílio Sales Gomes; História do Cinema Brasileiro; Comédia Musical; Rio de Janeiro.

\section{Abstract}

In this article, I analyze a completely unknown part of Paulo Emílio Sales Gomes' intellectual trajectory: the manuscripts of the course The films in the city (1966), a missing link between the historical research he carried out on Brazilian cinema, before and after the civil-military coup (1964). Here, I focus only on how Paulo Emílio investigates the genesis of musical comedies, considered the most expressive genre of Brazilian cinema, in cultural manifestations and female physiognomies of Rio de Janeiro, in the 19th century. Reassembling a mosaic of reading indications and transcriptions, I analyze how the cultural expressiveness of musical comedy is interpreted from the perspective of a long-term economic, psychological, social and cultural history.

Keywords: Paulo Emílio Sales Gomes; History of Brazilian Cinema; Musical Comedy; Rio de Janeiro.

O curso Os filmes na cidade (1966) é algo completamente desconhecido na trajetória intelectual do crítico e historiador de cinema Paulo Emílio Sales Gomes. O 
curso situa-se entre os textos históricos sobre o cinema brasileiro que publicou no Suplemento Literário do jornal O Estado de São Paulo no início da década de 1960 e os trabalhos de maior fôlego publicados a partir do ensaio Panorama do Cinema Brasileiro (1966), concebido como parte das comemorações dos 70 anos do cinema nacional.

Apesar do grande volume de pesquisas e publicações que anima os debates sobre o grande relevo do intelectual para a cultura brasileira ${ }^{3}$, pouco se sabe desse estudo histórico, econômico, social, psicológico e cultural que Paulo Emílio realizou sobre o Brasil no século XIX. Há um motivo bastante simples para esse fato. Os estudos sobre o século XIX encontravam-se cifrados, codificados, algumas vezes dispersos na base de dados do Centro de Documentação e Pesquisa da Cinemateca Brasileira. Foi preciso aliar ao trabalho histórico técnicas de arquivo levadas adiante como parte das comemorações do Festival 100 Paulo Emílio (2016), realizado pela instituição no centenário de seu fundador.

Amparando-se no trabalho de Olga Futemma Arquivo Paulo Emilio Salles Gomes: rastros de perícia, método e intuição (2006), nosso trabalho finalizou a identificação da produção intelectual de Paulo Emílio ainda não processada, mas o decisivo aqui se materializou com sua digitalização integral. Isso permitiu o cotejo global entre todos os manuscritos conservados pela Cinemateca, considerando aspectos como a acidificação do papel, caligrafia, tinta, marcas de ferrugem, temas - além da presença de algumas datas que facilitaram a montagem de um mosaico que revelou a dimensão dos estudos históricos de Paulo Emílio.

Nas primeiras aulas do curso, realizadas em maio de 1966, Paulo Emílio apresentou a fisionomia econômica, técnica e psicológica da formação do Brasil no século XIX ${ }^{4}$. Após essa introdução, as anotações das aulas seguintes (09 e 16/05) mais parecem uma etnografia da cidade do Rio de Janeiro. Nas duas aulas, Paulo Emílio apresentou e interpretou a história do teatro, dança, música, literatura, festejos cívicos e religiosos, entrudo e carnaval, fisionomias femininas e alguns esportes como elementos que persistem no gosto do público brasileiro ao longo de um século e meio.

Nessas aulas, a exposição dos temas foi dividida em dois períodos: o primeiro, entre cerca de 1810 e 1850, e o segundo, entre 1850 e 1896, data da chegada do omniógrafo ao Brasil. Nesse intuito, Paulo Emílio repete a divisão periódica adotada no Panorama do Cinema Brasileiro (1966), divergindo da montagem narrativa da primeira aula do curso, que havia tratado de todo o século XIX.

\footnotetext{
${ }^{3}$ José Inácio Melo Souza (2002), Arthur Autran (2003), Adilson Mendes (2013), Pedro Plaza Pinto (2010), Fausto Douglas Correia Jr. (2010), Carlos Roberto de Souza (2009), Carlos Augusto Calil (2015), Eduardo Morettin e Ismail Xavier (2015).

${ }^{4}$ Paulo Emílio e Os filmes na cidade (1966): economia, cultura laboral e mentalidade no século XIX. Trabalho submetido à Revista de Teoria da História (UFG).
} 
Diante das duas opções narrativas, uma periódica e outra temática, optaremos pela articulação dos temas tratados nas duas aulas para elucidar a fisionomia da música, dança, teatro e das mulheres que cativavam o imaginário social entre 1810 e 1895. Nesse recorte temático, veremos como Paulo Emílio examina esses aspectos da cultura brasileira a partir dos relatos de viajantes estrangeiros: O Rio de Janeiro como é (18241826), Uma vez e nunca mais, Contribuições de um diário para a história atual, os costumes e especialmente a situação da tropa estrangeira na capital do Brasil (1829; 2000), do militar prussiano Carl Schlichthorst; O Rio de Janeiro visto por dois prussianos em 1819 (1832; 1966), de Theodor von Leithold e Ludwig von Rango; e o relato do comerciante inglês John Lucoock, Notas sobre o Rio de Janeiro e partes meridionais do Brasil tomadas durante uma estada de dez anos nesse país, de 1808 a 1818 (1820; 1942). Ao lado dos relatos de viagem, as obras de referência mobilizadas por Paulo Emílio são: Aparência do Rio de Janeiro e Notícia histórica e descritiva da cidade (1949), de Gastão Cruls; Corografia do Distrito Federal (1949), de Mario da Veiga Cabral; Machado de Assis: Estudo Crítico e Biográfico (1936), de Lúcia Miguel Pereira; Arthur Azevedo e sua época (1966), de R. Magalhães Júnior; Cavaquinho e Saxofone (1940), de Alcântara Machado.

A partir dessas obras, Paulo Emílio realizou um panorama que parte da chegada da família real portuguesa (1808) e se estende por todo o século XIX. Dos temas trabalhados na aula do dia 09, restaram apenas fichamentos bibliográficos e inúmeras indicações de paginação das obras supracitadas, por vezes acompanhadas de palavraschave, ou em algumas vezes, citações transcritas integralmente, enquanto a aula do dia 16/05 é acompanhada de manuscrito ordenador da exposição, tal qual o que suportou a primeira aula do curso (04/05). Diante dessa diversidade documental, interpretaremos essa constelação de fragmentos à luz das produções anteriores e posteriores de Paulo Emílio para, com isso, revelar a gênese de sua interpretação sobre a expressividade cultural das comédias musicais no cinema brasileiro.

\section{Música, dança, cantos de trabalho e poesia}

Em seu estudo sobre a fisionomia cultural do Rio de Janeiro, Paulo Emílio adota como ponto de partida o livro O Rio de Janeiro como é (1824-1826), de Carl Schlichthorst, um militar, engenheiro e escritor alemão que veio ao Brasil em 1824 num grupo de 192 colonos, 60 soldados e 30 oficiais, alistando-se no Corpo de Estrangeiros como tenente de granadeiros alemães contratados pelo Primeiro Reinado para combater rebeliões nas províncias e lutar em guerras externas, como nos informa Gustavo Barroso em sua introdução à republicação do livro (SCHLICHTHORST, 2000). 
As anotações de Paulo Emílio nos conduzem ao primeiro aspecto observado por Schlichthorst em nossa fisionomia: "em país algum, a música" era "tão apreciada" como no Brasil. Não havia entre nós "músicos excelentes, mas todos sem exceção gostam dessa arte", apreciada tanto "pela gente educada da população quanto pelos escravos" (GOMES, 1966: PE/PI 0489). Embora não possuíssemos a mesma excelência técnica que seus conterrâneos prussianos, destacava-se aqui a "delicadeza" com que as modinhas eram executadas com a guitarra, não aquele "pesado instrumento" conhecido por seus conterrâneos, mas a chamada guitarra mourisca, com 12 cordas de metal, das quais nós brasileiros tirávamos "o mais engenhoso partido. Se o cantor tem talento, as improvisa. Ouvi diversos [músicos] que atingiram grande perfeição nessa difícil arte". Schlichthorst não sabia se admirava mais "o primor da forma ou o espírito e delicadeza dos sentimentos expressos" pelas modinhas (SCHLICHTHORST, 2000: 130131).

O comentário revela parcela importante da fisionomia musical nacional: a destreza na execução de instrumentos musicais mais simples, embora esse aspecto fosse superado pelo improviso e talento pessoal que nos distinguia do rigor formal da música clássica prussiana. A partir da obra de Schlichthorst, Paulo Emílio afirma que nesse período, entre 1824 e 1826, a música se fazia presente na vida da cidade, impulsionada pelo ímpeto de uma mocidade que organizava seus bailes em residências particulares para compensar a falta de bailes públicos.

Recorrendo ao livro O Rio de Janeiro visto por dois prussianos em 1819, de Theodor von Leithold e Ludwig von Rango, Paulo Emílio nos atenta que cinco anos antes, "jantares, bailes, reuniões em casas particulares" eram coisas que não se conheciam (LEITHOLD; RANGO, 1966: 64). No livro, Leithold reclama do isolamento afirmando ser necessário ser um segundo Timón de Fliunte 5 "para se sentir feliz no Rio de Janeiro e suas vizinhanças", pois não havia "vida mundana ou reuniões sociais, excluído o teatro". O viajante ficava em seu quarto "isolado e morto para o resto do mundo" (Idem: 72), com exceção das "noites de espetáculo", que começavam às oito da noite e duravam até a meia-noite, quando "as ruas da cidade fica[va]m como mortas" (Idem: 28). Leithold explicava que a pouca ocorrência de bailes se devia ao grande volume de mosquitos. As mulheres, com seus trajes "decotados além do que pede a moda", eram as que mais sofriam. Com maior área disponível à ação aos insetos, elas ficavam "não menos vermelhas" que a pele "dos soldados passados pelas varas" - em outras palavras, castigados fisicamente. Apesar da pouca frequência, esses bailes,

${ }^{5}$ Filósofo cético grego (320 a.C. ca. 230 a.C), autor dos poemas satíricos. A menção de Leithold se deve ao paralelo com um estado de humor disposto a rir e se divertir com a própria desgraça, ou a dos demais ao seu entorno. 
quando ocorriam, se destacavam pelo volume de pessoas amontoadas que, enquanto dançavam, pisavam nos pés umas das outras, em um ambiente quente, com um ar bastante saturado que dificultava a respiração (Idem: 76).

Após apresentar um retrato dos poucos bailes da corte, das modinhas e da guitarra, Paulo Emílio dirige sua atenção para os cantos e as danças dos escravos, ambientadas frequentemente em terrenos baldios, repletos de gente alegre. Quando se estava triste, Schlichthorst afirma que "bastava procurá-los". A descrição que o oficial faz da fisionomia dos brasileiros é transcrita na íntegra por Paulo Emílio: nossa natureza melancólica, muito sensual, cerimoniosa e desconfiada eram "qualidades [...] que não produzem a verdadeira alegria". Schlichthorst atribui essa fisionomia à "inconsciência do negro", que deixava "falar o que o momento Ihe propicia, sem cuidados sobre o futuro" (GOMES, 1966: PE/PI 0489).

Essa despreocupação em relação à moral europeia é mobilizada como explicação para a sensualidade com a qual os negros dançavam o "fado", dança "predileta" que consistia "em um movimento trêmulo do corpo que, suavemente embalado, exprime os sentimentos mais sensuais de um modo tão natural como indecente". A dança era tão "encantadora" que "muitas vezes os dançarinos europeus" as imitavam em suas apresentações "no Teatro de São Pedro de Alcântara, recebendo aplausos entusiásticos" (Idem).

Na transcrição, Paulo Emílio interpreta a melancolia e a dança dos escravos em relação à falta de expectativa com o futuro para explicar sua sensualidade singular. Nesse sentido, sua imitação pelos estrangeiros que aqui ganhavam a vida sugere a necessidade de adequação à fisionomia do público e sua preferência pela música e pela dança local. Essa característica, inscrita na longa duração, poderia figurar na base de uma explicação para a atratividade exercida pelos filmes cantantes e pelas comédias musicais no século seguinte. O paralelo com as comédias musicais, apreciada por um público de "ocupados", será um importante exemplo da inadequação dos filmes de Walter Hugo Khouri a um público mais amplo, considerados mais aprazíveis a um público elitizado, de "ocupantes" - terminologias que estabeleceu com maior precisão em Cinema: trajetória no subdesenvolvimento (1973). Essa característica já havia sido identificada por Leithold, especialmente quando revela ao leitor seu repúdio pela dança popular, cujo sucesso é explicado por sua vulgaridade: uma prova clara do "quanto o povo está atrasado em qualquer manifestação de cultura" (LEITHOLD; RANGO, 1966: 145). Delimitando a fisionomia da dança brasileira, Rango afirma que a execução das danças estrangeiras chegava a ser sofrível. O comentário sublinhado por Paulo Emílio possui sugestões importantes sobre nossa incapacidade de copiar as danças estrangeiras, restando-nos quando existia o esforço, adequá-las às nossas 
características: "sensualidade, naturalidade e desprendimento dos gestos" (GOMES, 1966: PE/PI 0489).

Além da música e da dança, Paulo Emílio descreve o retrato social que Leithold concebe dos cantos de trabalho dos escravos: "Quanto mais pesado parece ser o trabalho, mais selvagemente se põem a cantar, como se sua força fosse estimulada pelo coro", semelhante aos "nossos". Como instrumento, eles usam "uma gaita presa a uma tábua em que estão esticadas duas cordas", que tal como o tradutor do livro adverte, poderia ser tanto uma marimba congolesa ou um berimbau de barriga. Munidos desse instrumento, eles tocavam caminhando ou reunidos para dançar à porta de uma "venda" (LEITHOLD; RANGO, 1966: 151).

Num dos episódios narrados pelo viajante, ele relembra como havia se surpreendido ao ver os negros escravizados dançarem "indecentemente com grande gritaria e gesticulação", mas o que mais Ihe surpreendeu foi um negro grisalho que chegou carregando um pesado fardo sobre a cabeça, e assim permaneceu por um quarto de hora, sem baixar o peso. "Os primeiros se entusiasmaram tanto com o velho que o cercaram e, dançando aos gritos, deram umas quantas voltas em torno dele" (Idem: 34). Segundo o viajante, ouvia-se o tempo todo o "canto monótono dos negros acompanhado de instrumentos que eles próprios constroem": mesmo "nos mais rudes trabalhos, sempre há um que canta ou faz soar as cordas" (Idem: 151).

Recorrendo a outros exemplos dos cantos de trabalho, que no cinema brasileiro foram tratados por cineastas como Humberto Mauro e Leon Hirszman (HAMBURGER; GOMES, 2017), Paulo Emílio evoca o passeio de Schlichthorst pela cidade, a partir do qual descreve os negros carregando em suas costas e cabeças cestos e malas muito pesadas enquanto entoavam sob o sol tropical cantares com "uma delicadeza de sentimentos que não envergonharia um poeta europeu de primeira plana". Para exemplificar a qualidade das canções de trabalho, Schlichthorst transcreve em seu livro as "habilidosas rimas" de um negro que caminhava "tristemente" carregando uma mala pesada: "Vou carregando por meus pecados / Mala de branco pra viajar / Quem dera ao Tonho, pobre do negro / Para sua terra poder voltar" (SCHLICHTHORST, 2000: 130131).

Na percepção de Paulo Emílio, esses cantos eram verdadeiras poesias, como afirma a partir da articulação das citações transcritas da obra de Schlichthorst, ou mesmo uma "literatura oral" que, como milhares de outras, ainda se ouvia nas cidades e nos campos, mas que não possuíam registros como as poesias: elas "se desfizeram no ar azulado, como o perfume dos laranjais, ao leve roçar da brisa", como definiu o oficial alemão. Algo lamentável pois, segundo ele, o amor fazia de nós brasileiros "poetas quase sem exceção. A língua também favorece a poesia. Fiel e cruel, coração e ladrão, 
amá-lo e matá-lo, e ilimitado número de outras rimas facilmente se oferecem". Era com versos que as cartas amorosas eram redigidas (GOMES, 1966: PE/PI 0489).

Munido da obra de Schlichthorst, Paulo Emílio compara a produção poética brasileira à europeia e julga que nossa fisionomia seria a de um povo que contempla as riquezas naturais que nos rodeiam e as paixões que pulsam ao peito. Éramos diferentes dos europeus, que se achavam "no mesmo grau na sociedade burguesa", éramos supersticiosos e alheios aos conhecimentos amplamente divulgados na Europa, mas nossos pensamentos eram rápidos como o relâmpago e nosso instinto do belo era sempre seguro, de modo que sabíamos exprimir bem nossas sensações em uma língua simples, maleável e de singular harmonia, pois paixões veementes agitavam nossa alma, e conclui: "Todas essas qualidades, se forem bem desenvolvidas pela educação, devem produzir grandes poetas" (SCHLICHTHORST, 2000: 162), expectativa à qual Paulo Emílio adere anotando em seu manuscrito: "e realmente... Gonçalves Dias, Castro Alves" (GOMES, 1966: PE/PI 0489).

\section{Teatro: espaços e manifestações artísticas}

A exposição de Paulo Emílio sobre a história da música, da dança, dos cantos de trabalho e da poesia no Rio de Janeiro à época de $\mathrm{D}$. Pedro I é seguida da descrição dos espetáculos que ambientavam o teatro da cidade. Nesse propósito, o historiador recorre ao livro Notas sobre o Rio de Janeiro e partes meridionais do Brasil, do comerciante inglês John Lucoock, para descrever o teatro e os espetáculos do período (1813). Segundo o inglês, o teatro era o lugar de divertimento e recreação mais importante de uma cidade, conceito compartilhado com seus habitantes. Ele descreve o teatro como uma "casa miserável, apertada e sombria. Por dentro, sua forma é oval, tendo numa das extremidades o palco e na outra o camarote real que ocupa toda a parede norte do edifício". Havia ainda outros camarotes desprovidos de janelas ou entradas de ar, extremamente abafados e fechados pela frente por "um gradeado de rótula, bizarramente pintado". A plateia era dividida em duas partes: os espectadores que ficavam à frente dos camarotes reais sentavam em tamboretes com uma trave de encosto; já a que ficava abaixo do camarote real era separada por um baluarte, onde os espectadores assistiam prostrados em pé. A iluminação do local era realizada por candeeiros fixados aos pilares de madeira que sustentavam os camarotes (LUCOOCK, 1942: 60-61).

Após a descrição física do espaço, Paulo Emílio nos conduz as suas manifestações artísticas (GOMES, 1966: PE/PI 0489): "A orquestra é reduzida, inconveniente e mal recrutada. Muitas das peças dramáticas contêm cenas que uma pequeníssima dose de bom-senso e bom gosto haveria de banir para sempre do palco". 
Recordando a última apresentação que havia assistido, Lucoock descreve o que considerou ser uma "catástrofe de tragédia": "A heroína, trajada de musselina branca, devia ser morta, enquanto o pano estava abaixado, separando-se-lhe a cabeça do corpo". Isso, pensava o comerciante, "devia constituir o fim do seu papel, em qualquer teatro que não fosse brasileiro", porque na cena seguinte o pano era novamente levantado "sem outro fim que o de exibir ao público o corpo decapitado da dama, sentado direito numa poltrona, com o sangue borbulhando de seu pescoço e correndo pelo seu vestido abaixo". Na cena descrita por Lucoock, os atores e atrizes eram igualmente lastimáveis, de modo que apenas um deles apresentava algo parecido "com o verdadeiro espírito da comédia", mas também havia a representação de vilões vestidos de "padres marotos", cuja ousadia havia surpreendido o comerciante (LUCOOCK, 1942: 60-61).

Assim como a comicidade será parte importante dos divertimentos e do cinema brasileiro, a representação de padres menos austeros que a imagem construída pelos sacerdotes europeus será tema de filmes como Anchieta entre o amor e a religião (1932), de Arturo Carrari, produção paulista que Paulo Emílio irá situar, na palestra $O$ cinema brasileiro na década de 1930, num terreno intermediário entre os filmes eclesiásticos e eróticos (GOMES, 1973: PE/PI 0296).

$\mathrm{Na}$ sequência de sua descrição dos espaços e das atrações, Paulo Emílio emprega o livro de Lucoock para oferecer um panorama do desenvolvimento que a cidade havia assistido a partir da chegada da família real portuguesa ao Brasil. Novas ruas e mercados foram construídos, sendo os antigos reformados e pintados, como ocorreu também com as casas de família. Ao lado do desenvolvimento da cidade, somou-se o grande fluxo migratório proveniente tanto de outras partes do país quanto da Europa (LUCOOCK, 1942: 162).

O desenvolvimento da cidade observado pelo viajante serviu a Paulo Emílio como um exemplo de como o teatro miserável e os espetáculos catastróficos descritos por Lucoock em 1813 foram revitalizados, como podemos perceber na descrição que faz Leithold (1819) do Real Teatro de São João, inaugurado em 1813 e situado no Largo do Rossio - edifício tão grande, mas não tão largo quanto os equivalentes na Prússia. No local, realizavam-se quatro ou cinco representações por semana, que variavam entre comédias, dramas e tragédias encenadas em português, mas que eram pouco concorridas pelo público em comparação às "óperas italianas acompanhadas de bailados", embora a orquestra fosse péssima - o que não impediu o viajante de se emocionar com o recital da cantora lírica Angélica Catalani (LEITHOLD; RANGO, 1966: p. 14-15). 
A orquestra era bastante reduzida, "numa palavra, miserável". Apenas um flautista francês e um violoncelista chamaram sua atenção, enquanto que os demais violinistas estavam "abaixo da crítica". Já os bailados não eram maus, atraindo, como em Paris, um público sempre numeroso e entusiasta: "cada aparição do solista e das dançarinas é aplaudida, o que acontece também com os cantores do lírico, aplausos esses que são todas as vezes reverentemente agradecidos". Havia ainda "grandes espetáculos" de balé, como A morte de Pirro e Paulo e Virgínia, etc., organizados por franceses que não apenas os protagonizavam, como também realizavam bailados cômicos e ensinavam os filhos e as filhas dos ricos fidalgos da cidade os segredos dos bailados europeus. Leithold apresenta o caso de um jovem espanhol e sua irmã que eram satisfatórios na arte, apenas encontrando rivalidade à altura nos solos de uma morena, que dançava como se tivesse sido "mordida por uma tarântula" - bailados que ao lado da ópera italiana faziam mais sucesso que as peças encenadas em português (Idem: 15-16).

Comparando o teatro à ópera e aos bailados, Paulo Emílio cita a descrição de Rango, para quem essa arte no Rio de Janeiro era "um grande picadeiro, destituído de gosto e arte, é a sede de um bando que tem a petulância de se intitular atores e atrizes", mas que mesmo assim, gozavam de aplausos ao final das atuações. Ao prussiano, elas não provocavam nada mais do que o riso, considerando-as "uma pantomima de má qualidade", distantes de "qualquer ideia de arte". Mesmo as óperas "eram cantadas bem sofrivelmente". Entre o intervalo de dois atos da ópera, era de costume apresentar um bailado, parte "que os portugueses mais gostam", pois após os bailados metade do público se retirava (Idem: 144-145).

Após o incêndio do Real Theatro São João (1824), o espaço foi reaberto sob o nome de Imperial Teatro de São Pedro de Alcântara (1826), totalmente reconstruído. A partir do livro de Schlichthorst, Paulo Emílio descreve a organização interna do novo teatro, que continha "110 camarotes em quatro ordens, com o espaçoso e novíssimo camarote imperial ao centro". Ao todo, os camarotes poderiam acomodar cerca de 300 pessoas, enquanto a plateia detinha a capacidade de 600 pessoas. Os camarotes para até cinco pessoas custavam de 3 a 5 mil réis, enquanto o preço da plateia era 1000 réis, dado importante para Paulo Emílio posicionar o espaço como um nobre lugar de espetáculos, apesar das manifestações de desordem de um público nada plebeu. Do ponto de vista técnico, o novo teatro possuía um sistema de ventilação que evitava o calor excessivo observado nos teatros tratados anteriormente, e contava com uma "pintura rica e de bom gosto, azul e ouro" (SCHLICHTHORST, 2000: 126).

No teatro, as orquestras que se apresentavam eram completas, contando com quase cem músicos, tal qual as europeias, e havia ainda apresentações de cantoras e 
dos Castrati italianos. Mas a atração que mais chamou atenção do oficial prussiano foi a performance da dançarina brasileira Baratinha, "uma das moças mais sedutoras que se possam existir". Segundo o viajante, as qualidades da dançarina não se manifestavam apenas ao dançar os estilos estrangeiros, bastante rigorosos do ponto de vista formal: a força de Baratinha residia em sua naturalidade. Pesaroso, Schlichthorst observou que pouco a pouco, a dança francesa suplantava a nacional com a chegada dos "afamados mestres de dança parisiense", que, dançando, mais pareciam "um boneco de engonço a mover braços e pernas conforme se puxa o fio", se comparados à grande expressão da dança do fado e do fandango, executada pelos negros escravos, ou mesmo uma gavota, dança popular francesa, que preferia ver dançada por brasileiros e espanhóis do que pelos próprios franceses. "Até a valsa alemã este povo sabe tirar a cansativa monotonia. Ela é dançada no Brasil de maneira a exprimir a ideia do amor que nega e consente" (SCHLICHTHORST, 2000:127). Nessa atmosfera, a dançarina brasileira Baratinha era a maior atração, até a chegada de outros dançarinos estrangeiros que com ela rivalizaram. Na atenção que confere a esse processo, Paulo Emílio vê na dança o que Lourival Gomes Machado compreendeu no caso do barroco brasileiro, em seu ápice e portador de uma fisionomia própria à época da chegada da Missão Francesa ao Brasil (FERNANDES, 2012: 55).

Partindo desses relatos, Paulo Emílio encontra com seus estudos as raízes do gosto brasileiro e português para os bailados e a ópera em contraposição ao teatro, menos aprazível aos espectadores locais. É interessante notar ainda que a introdução dos bailados entre as representações teatrais será, anos depois, uma fórmula explorada pelas revistas e, posteriormente, pelas comédias musicais e chanchadas.

Para apreender a atmosfera do teatro, Paulo Emílio recorre à descrição que o conselheiro real, diplomata e historiador Antônio Menezes Vasconcelos de Drummond fez do Real Teatro de São João à época da Independência (1822), citada no livro Corografia do Distrito Federal (1949), de Mario da Veiga Cabral. No trecho transcrito por Paulo Emílio, nota-se como o teatro "era o local onde se cometiam todas as noites as mais inauditas cenas de anarquia social em presença do Rei e depois do Príncipe Regente" (GOMES, 1966: PE/PI 0489), um tipo específico de ritual de poder centrado na exaltação da tolerância do monarca.

Outro tema tratado por Cabral chamou a atenção de Paulo Emílio: as representações eram continuadamente interrompidas "por miseráveis poetas que repetiam maus e grosseiros versos, muitas vezes insultantes à majestade que se achava presente", um saboroso momento de desforra contra a autoridade de D. Pedro I, mas também contra os fidalgos lá presentes. Nas palavras de Cabral, a "plateia exercia uma 
tirania de que não há exemplo. Nem as senhoras ficavam ao abrigo. As senhoras honestas deixaram de frequentar" (Idem).

\section{As revistas de Arthur Azevedo}

A propósito das manifestações artísticas e culturais da segunda metade do século XIX, Paulo Emílio concentra-se na descrição das primeiras revistas apresentadas no Rio de Janeiro, amparando-se no livro Arthur Azevedo e sua época (1966), de R. Magalhães Júnior. No Brasil, as primeiras revistas "eram uma espécie de capitulação dos principais acontecimentos do ano que se encerrava", uma mescla de "opereta e comédia, com muita sátira social e política" que fazia do gênero uma espécie de "teatro adaptado ao gosto do consumidor popular" (MAGALHÃES JÚNIOR, 1966: 30). Paulo Emílio pretendia demonstrar que a sátira às autoridades, tanto nos poemas satíricos declamados no Teatro São João à época da Independência quanto as sátiras políticas das revistas, encontravam lugar especial no gosto dos espectadores cariocas - traço persistente na cultura brasileira que se prolongaria nas comédias musicais cinematográficas.

O principal tradutor dessas revistas era Arthur Azevedo. Muitas vezes, a tradução se convertia em uma clara traição às revistas estrangeiras: "Se desconfiava do êxito de um texto, numa versão literal, tangenciava, adaptando-o, deformando-o, parodiando-o, imitando-o", com o propósito de "manter ou realçar a graça, os efeitos cômicos, a vivacidade, que de outro modo desvaneceriam". Essas adaptações procuravam se adequar ao gosto do público "ingênuo e pouco refinado" do teatro da época, num momento em que "a chalaça grossa fazia com que as galerias e plateias tivessem convulsões de riso, mas as invenções mais inteligentes, os diálogos mais sutis, as frases mais brilhantes passavam despercebidas, quando não provocavam bocejos de tédio" (Idem).

Em seu manuscrito, Paulo Emílio cita a paródia da revista La fille de Madame Angot, que Arthur Azevedo havia transformado em A filha de Maria Angú, adaptando a história, os ambientes e os personagens à paisagem carioca (GOMES, 1966: PE/PI 0490). "O êxito foi enorme. Tão grande que outros imediatamente tentaram explorar o mesmo veio de ouro" (MAGALHÃES JÚNIOR, 1966: p. 30), como havia acontecido posteriormente na história do cinema brasileiro com os filmes de crimes, cantantes e, posteriormente, com o musical Coisas Nossas, analisado no Panorama (1966). As paródias de Azevedo davam mostras de aspectos notados por Paulo Emílio em textos anteriores como Decepção e Esperança (1960), no qual é valorizado o apelo dos filmes brasileiros a um "público mais rústico" (GOMES, 1982b: p. 150) e no valor atribuído às 
comédias musicais para a bela época do cinema brasileiro, como sustenta no Panorama (2016: 159).

No curso, Paulo Emílio recorre ao livro Cavaquinho e Saxofone (1940), de Alcântara Machado, em que o autor afirma que o teatro brasileiro até a década de 1920 ainda não havia saído do romantismo, e muito menos havia se dado ao trabalho de nacionalizá-lo: "Brasileirismo só existe na revista e na burleta. Essas refletem qualquer coisa nossa. Nelas é que a gente vai encontrar, deformado e arramalhado embora, um pouco do que somos. O espírito do nosso povo tem nela o seu espelhinho de turco ordinário e barato", e acrescentaria que a revista "nem é nacional, nem é universal" (GOMES, 1966: PE/PI 0494). Nesse contexto, as revistas são interpretadas como uma expressão própria da cultura brasileira, importadas do estrangeiro, mas possuidoras de uma fisionomia nacional própria. As reflexões de Magalhães Jr. sobre as revistas encontram ressonância na compreensão de Paulo Emílio sobre nossa formação cultural, tardia e colonial: "nossa incompetência criativa em copiar" - uma das teses que sustentou em Cinema: trajetória no subdesenvolvimento (GOMES, 2016: 189-190).

Após o sucesso da revista $A$ filha de Maria Angú, Paulo Emílio cita o caso de $O$ Bilontra como o momento em que o gênero "conquistou em definitivo a estima do público". Estava lançado o novo gênero teatral, mas "para firmar-se definitivamente precisava a revista de alguma coisa que mexesse, de fato, com as camadas populares, levando-as a adotar como seu, aquele teatro". Magalhães Jr. afirmou que a revista $O$ Bilontra arrancou do público do teatro Lucinda "a gargalhada que abalou o Rio de Janeiro" apresentando aquele personagem clássico urbano, "sinônimo de peralta, trapaceiro, golpista, malandro" (MAGALHÃES JÚNIOR, 1966: 44-46), representado com muita astúcia nas chanchadas cariocas da década de 1940 e 1950. Em Panorama (1966), Paulo Emílio sintetiza essa representação nas chanchadas de "Zé Trindade, personagem bizarro e rico, cafajeste maduro sem o menor encanto, mas cuja confiança em si próprio fascina as mulheres" (GOMES, 2016: 162).

Outros temas foram explorados pela revista, como a atração $A$ Inana, assim descrita por Paulo Emílio: "Por um jogo de espelhos uma mulher parecia flutuar no ar". A grande popularidade do "espetáculo ótico" se reflete na expressão popular "vai começar a Inana", atração do teatro do comerciante Tcheco Frederico Figner, que se dedicava também à comercialização de gramofones (GOMES, 1966, PE/PI0490). A popularidade da atração foi tamanha que figurou como tema na revista de Arthur de Azevedo, O Jagunço: "Eu sou a Inana formosa; Que se suspende no ar; E a multidão curiosa; Faz todo o dia pasmar; O meu fiel empresário; Reclame sabe fazer; E muito bom numerário; Tem sabido suspender; Na porta sempre a gritar; A Inana vai começar" (GOMES, 1966: PE/PI 0490). 
Além da revista, a expressividade cultural da atração é exemplificada pelo carro e pelo pufe que a sociedade carnavalesca dos Fenianos dedicou à atração: "Por isso, bom povo, apronta; As mãos para palmas dar; Quando este carro vistoso; For passando, povo amigo; Gritai bem, gritai comigo: Vai a Inana começar". No teatro de Figner, localizado na Rua do Ouvidor, havia ainda o Taumateon, atração que consistia em uma "série de transformações, sem que se saiba como aparecem sucessivamente", como "uma estrela simbolizando a América desconhecida, uma mulher representando a América selvagem, depois um ramo e flores, figuras de mulheres, representando a guerra e a morte, e finalmente, a República" (GOMES, 1966: PE/PI 0490).

\section{Fisionomias femininas, nacionais e estrangeira}

Além da música, teatro, dança e das revistas - manifestações culturais fundamentais para a composição das comédias musicais -, Paulo Emílio descreveu alguns aspectos das fisionomias femininas que impactavam o imaginário social da então capital federal ao longo do século XIX e que embasam sua interpretação da representação feminina no cinema brasileiro. A partir do relato de Schlichthorst, tomamos nota de que, no período, apesar de toda vigilância que recaia sobre as "senhoras e moças de família", elas não raras vezes conseguiam "burlar todas as precauções e satisfazer seus desejos de aventura". As que eram apanhadas eram enviadas ao Convento da Ajuda, "vasto edifício que contém mais de 600 freiras e pensionistas, na maioria vítimas da paixão que Camões cantara", mas que diferentemente dos conventos europeus, o brasileiro oferecia "asilo seguro e decente a uma porção de meninas que, sem isso, se perderiam na barafunda dum mundo por demais sedutor" (SCHLICHTHORST, 2000: 132).

Em sua nota, Paulo Emílio relembra que em 1911 o convento foi vendido, e em 1923 foi demolido para dar lugar à Cinelândia - mas seu real interesse para a exposição talvez possa residir no interesse pelo documentário brasileiro desaparecido Visita ao Convento da Ajuda (1911). Essa instituição tinha como propósito, tal como observou Schlichthorst e transcreveu Paulo Emílio, prevenir que o amor levasse ao "crime", "geralmente cometido por mulheres. Os homens contentam-se em aferrolhá-las, quando não confiam mais na sua fidelidade" (GOMES, 1966: PE/PI 0489), dúvida que atormentou o personagem Bentinho em Capitu, obra de Machado de Assis, pouco tempo depois adaptada para o cinema por Paulo Emílio, Paulo César Saraceni e Lygia Fagundes Teles.

As anotações de Paulo Emílio nos remetem às impressões de Leithold sobre a pouca presença das mulheres brancas nas ruas, pois muitas casas possuíam capelas e oratórios que tornavam desnecessário sair de casa para rezar. "Mas que não se acredite 
que essa vida claustral indica uma vida religiosa exclusiva. As intrigas amorosas não são raras. As mulheres vivem apenas para rezar e amar". Leithold as descreve afirmando que jamais havia encontrado "reunidas tantas pedras preciosas e pérolas de extraordinária beleza quanto nos beija-mãos de gala [Ritual de poder] e no teatro, por certo as duas únicas ocasiões em que elas se exibem e dão asas a sua faceirice". Já os vestuários eram ousadamente decotados ao gosto da moda francesa e eram bordados a ouro e prata, aparência completada com quatro ou cinco plumas francesas de dois pés de comprimento, reclinadas sobre a fronte, ou ainda ao redor do pescoço e dos braços (LEITHOLD; RANGO, 1966: 30).

Nos camarotes do teatro, os cavalheiros conversavam com as tão luxuosas damas, enquanto que sua ocorrência na plateia era bastante pequena. Sobre as mulheres que ocupavam o camarote, Schlichthorst adverte seus leitores que, apesar de trajadas como princesas, metade delas eram profissionais do sexo, cujos preços pelos seus serviços eram dos mais elevados. Com a valorização da profissão, essas profissionais tinham uma vida luxuosa por serem brancas, e por esse motivo, eram tratadas como nobres (SCHLICHTHORST, 2000: 128-129). Leithold, exatamente na página indicada por Paulo Emílio, afirma que as profissionais do sexo no Rio de Janeiro eram brancas, negras e de todas as categorias, e em maior número que nas grandes cidades europeias, embora as mulheres negras não gozassem do glamour de suas colegas de profissão. À noite, elas tomavam as ruas "vestidas de tafetá preto ou de lã e envoltas em mantos. As de "primeira classe" saem também de suas casas acompanhadas de duas escravas e dois escravos, fazendo-se passar, com suas artimanhas, por damas de qualidade", sabendo como ninguém "pescar o estrangeiro em suas redes". A abordagem era frequentemente realizada por uma velha matrona que se prestava ao papel de alcoviteira. Prostrada na janela, ela anunciava os serviços de sua senhora com piscadelas, que avalizavam a concordância da casa com as intenções do cliente (LEITHOLD; RANGO, 1966: 32). Já Schlichthorst localiza a área do meretrício a partir da descrição que faz da Rua do Ouvidor, habitada por centenas de meretrizes francesas que em sua terra já eram aposentadas, mas que à noite, sob a luz de lampiões, dividiam a rua com escravos, policiais e músicos, passeando completamente envoltas em mantilhas ou capas escocesas (SCHLICHTHORST, 2000: 103).

\section{Da Rua do Ouvidor às telas cinema}

A partir da obra de Gastão Cruls, Aparência do Rio de Janeiro (1949), a fisionomia das atrizes do Álcazar e do Eldorado ganha relevo pela importância que detinha povoando a imaginário da capital. Esses locais "eram o pesadelo das famílias", nos quais "os velhos babosos, os maridos bilontras e a rapaziada bordelenga se davam 
rendez-vous todas as noites, para rentear as atrizes brejeiras e as cupletistas gaiatas que degelavam os mais idosos e rescaldavam os mais moços" (CRULS, 1949: 419).

Sobre esses espaços, Paulo Emílio emprega a referência de Cruls às impressões de Gobineau quando visitou o Rio de Janeiro: "Toda a vida dos habitantes do Rio se passa num horrível teatro da Rua do Ouvidor, chamado Álcazar". Na realidade, o Álcazar ficava nas proximidades da rua, a ela associado pela má fama que gozavam espaços como o restaurante Frères Provenceaux, que possuía na parte de cima do sobrado "uma pensão de meninas malcomportadas". Havia ainda as modistas que ali trabalhavam: "Aquelas modistas da Rua do Ouvidor eram uma tentação permanente e, também, devido à sua acessibilidade, um convite ao galanteio e à aventura". A presença dessas moças no imaginário social da cidade ganhava ainda mais saliência com o fato de que o "próprio D. Pedro I se envisgou por uma delas": Clemencia Saisset, mãe de um filho bastardo do Imperador, mulher maltratada por um marido que era facilmente enganado e que portava um brasão da casa de Bragança em suas vestes com certo orgulho (CRULS, 1949: 418).

O tratamento conferido por Paulo Emílio a essa atmosfera se deve ao "vínculo profundo entre a vida noturna e o teatro". As atrizes desses estabelecimentos haviam aberto uma séria competição com as modistas da Rua do Ouvidor pela preferência do público masculino. De todas as atrizes francesas do período, Aimée foi a que mais se destacou "pelas suas proezas amorosas" (CRULS, 1949: 419).

Estrela de primeira grandeza do Álcazar, Aimée viveu por um bom tempo no Rio de Janeiro e era vista como o "desespero de muita esposa e intranquilidade de muita mãe". Cruls narra em seu livro que quando a atriz deixou a cidade levando suas economias, que somavam "mais de um milhão e meio de francos", atestando seu sucesso na arte do amor, "as senhoras mais respeitáveis de Botafogo, mal dominando o contentamento, vieram para a praia soltar foguetes, enquanto o vapor se ia em direção à Barra, levando a famosa loureira" (CRULS, 1949: 419).

Em suas anotações, Paulo Emílio se apropria da obra de Cruls para narrar como a partida da atriz causou "muito desconsolo entre os seus afeiçoados", que para guardar uma lembrança da moça organizaram um "leilão do amor", no qual alguém chegou "aos 100 mil reis para ser dono de certo objeto que só é visto quando sai discretamente o criado-mudo". A atriz exerceu tamanho impacto no imaginário social que em 1864 "nem mesmo Machado de Assis se livrou dos encantamentos dessa Circe do tablado" (CRULS, 1949: 420), a quem se referiu como "um demoninho louro - uma figura leve, esbelta, graciosa - uma cabeça meio feminina meio angélica - uns olhos vivos - um nariz como o de Safo - uma boca amorosamente fresca, que parece ter sido formada por duas de Ovídio..." (GOMES, 1966: PE/PI 0495). 
Em seu manuscrito, Paulo Emílio sugere seguir a fonte empregada por Cruls em sua descrição de Aimée, assinalando a necessidade de "ver a citação toda no livro de Lúcia" Miguel Pereira, intitulado Machado de Assis: Estudo Crítico e Biográfico (1936), no qual a autora conjectura a possibilidade de algum envolvimento entre o escritor e a atriz a partir da análise de uma crônica de sua autoria publicada em julho de 1864, na qual dizia que "a francesinha não fazia somente, como acrescentava o cronista do diário, 'andar à roda muita cabeça branca', mas tinha o mesmo efeito sobre uma cabeça bem negra, sobre um jovem de sensibilidade aguçada demais, e, ao mesmo tempo, muito retraído, o que há de ter dificultado a aproximação" (PEREIRA, 1966: 105). Para refutar essa hipótese, Cruls argumenta que faltava a Machado requisitos como "beleza, elegância e audácia", além de que à época ele tinha "os bolsos muito murchos" (CRULS, 1949: 420).

No propósito de delinear algumas fisionomias femininas que ambientavam 0 imaginário social da então capital do império, Paulo Emílio recolheu em suas anotações informações sobre a Rua do Ouvidor, do meretrício e das dançarinas e atrizes de teatro para explorar todo o erotismo e sensualidade das mulheres brasileiras e estrangeiras que mais fascinavam o público masculino. As descrições dos viajantes nas décadas de 1810 e 1820 sobre os trajes das moças e a prostituição são apreendidas ao lado da singularidade erótica e sensual das modistas da Rua do Ouvidor e das atrizes do Álcazar para traçar a persistência de fisionomias femininas que, posteriormente, entrarão em um novo momento com o fenômeno das vedetes e o fascínio que exerciam. O relevo dado por Paulo Emílio à fisionomia feminina, a prostituição, ao erotismo e à sensualidade possui alguns motivos distintos, mas o principal será identificar qual seria essa fisionomia das atrizes mais apreciadas pelo público brasileiro, tal qual sugere fragmentariamente em trabalhos anteriores e posteriores.

\section{Cinema e erotismo}

No início da década de 1960, Paulo Emílio analisa o fenômeno da prostituição no artigo Cinema e Prostituição (novembro de 1961), no qual considera que "de um certo ângulo, as necessidades que o cinema satisfaz são as mesmas" que aquelas satisfeitas pela prostituição. "Essas necessidades talvez não estejam obrigatoriamente [...] condicionadas a esta ou aquela estrutura social", como defendia Máximo Gorki, pensando esse fenômeno como reflexo de uma sociedade desigual. Segundo Paulo Emílio, a prostituição deveria ser interpretada como a expressão "de algo permanente no homem". Para sua elucidação, deveríamos meditar sobre algumas "significações muito nítidas do fenômeno Brigitte Bardot, ou lembrar que para boa parte do público feminino, Rodolfo Valentino era um príncipe encantado", enquanto para outra parte, "ele 
era um imaginário gigolô". Outro exemplo poderia ser encontrado no mundo dos festivais de cinema, mais especificamente na aparição de um produtor cercado de estrelas, imagem que poderia ser facilmente associada a de um cafetão "excepcionalmente bemsucedido". A presença desse tema no imaginário social levanta a seguinte questão: por qual motivo os homens vão ao bordel? Paulo Emílio responde: "em busca de ficção" (GOMES, 1982b: 364-365).

No exame do fenômeno, Paulo Emílio analisa a ficção da "comédia do amor pago", na qual a representação da mulher seria "brechtiana", à medida que "guarda distância do personagem que representa", enquanto o homem "escorrega facilmente para a verdade interior de Stanislávski ou do Actor's Studio", mas com uma distinção importante: nos jovens, esse desejo de ficção é projetado para o futuro, "se manifesta na fala", nos "famosos diálogos dos adolescentes" com as profissionais do sexo: em público, "cínicos e grosseiros", no quarto, "sentimentais e tímidos". No caso dos adultos, a ficção que buscam é uma espécie de "bálsamo" para "ferimentos antigos", cujo "mecanismo compensatório é o silêncio", ou ainda, um laconismo queixoso ou agressivo. No cinema, esses sentimentos "revelariam estados de espírito muito próximos de seus comportamentos no bordel". No caso dos jovens, com a ficção cinematográfica surgiria um projeto, enquanto para os adultos o cinema não passava de um "ilusório calmante" (GOMES, 1982b: 364-365).

O relevo dado ao "amor pago" no curso Os filmes na cidade (1966) ainda possui outras razões, tal qual a que pode ser lida em Humanismo e Erotismo (1958). No artigo, Paulo Emílio analisa "o lado erótico da criação e do prazer artístico" num momento em que era grande a tendência em considerar o erótico "como uma raiz longínqua e em julgar que o mecanismo de filtragem e sublimação faz parte da natureza intrínseca do fenômeno artístico" (GOMES, 1982a: 394). Paulo Emílio estava convencido de que a vocação erótica do cinema era mais evidente do que em outras expressões artísticas, pois "sempre procurou exprimir o prazer físico ligado ao amor". O cinema, como arte industrial concebida para o grande público, havia se apresentado no início do século XX como "testemunho do anseio humano por concepções morais mais adaptadas à vida moderna". Ele rompeu barreiras mostrando primeiramente o beijo, e depois o ombro e 0 busto, até chegar ao nu, protagonizado por sex symbols do cinema estrangeiro como Vilma Banky, Constance Benneth, Ruth Roland e Pola Negri (GOMES, 1982a: 395-396).

No Panorama do Cinema Brasileiro (1966), Paulo Emílio entende que o erotismo foi muito importante para a formação do cinema brasileiro. O melodrama mundano Lucíola (1916), de Antônio Leal, é um excelente exemplo, trazendo a atriz Aurora Fúlgida como intérprete da "heroína de Alencar", que conferiu ao filme grande dose de um erotismo que havia cativado a imaginação de toda uma geração de 
estudantes (1916-17). A atriz era mais uma estrangeira que havia ligado seu destino ao Rio de Janeiro por um amor, assim como tantas outras atrizes estrangeiras, como Antônia Negri, ou a portuguesa Otília Amorim, que aparecia nua no filme Alma Sertaneja (1919), trazendo o erotismo dos cafés-concerto ao cinema. Apesar do feito memorável, Paulo Emílio afirma que a precursora na "audácia" foi Miss Ray, aparecendo "nua numa sequência com o demônio no Le Film du Diable" (1917). Havia ainda as atrizes Iolanda Dini e Ida Kerber - as mais expressivas do período. No que se refere aos atores, Paulo Emílio afirma que não havia nada de "especial a registrar", apenas o fato de que assim como "o fenômeno das atrizes principais, quase todos os astros são estrangeiros oriundos do teatro, predominando no Rio os portugueses e, em São Paulo, os italianos (GOMES, 2015: 139-140).

\section{Uma síntese possível}

No conjunto da exposição, procuramos sinalizar o parentesco de alguns temas do século XIX com os filmes brasileiros estudados por Paulo Emílio no Panorama (1966), mas nos parece que, no conjunto dos temas explorados em suas aulas, o filme que mais sintetiza o gosto do público brasileiro pela sátira, música, bailados, revistas, operetas e fisionomias femininas é Bonequinha de Seda (1936), de Oduvaldo Viana - comédia musical de grande "interesse e comunicabilidade" que conquistou para a Cinédia grande sucesso de bilheteria (Idem: 159). Além de reunir todos esses elementos, deve-se destacar como o filme retoma o mesmo imaginário suscitado pelas modistas francesas da Rua do Ouvidor, ao narrar a história da filha de um alfaiate suburbano imerso em dívidas que se veste suntuosamente e passa a frequentar as altas rodas sociais da cidade, se apresentando como uma moça educada em Paris. Os homens caem aos seus pés e as mulheres tentam lhe imitar, até que a farsa é descoberta e se revela toda a hipocrisia da alta sociedade carioca, satirizada enquanto enganada pela moça desforra dos suburbanos contra uma elite opulenta.

Ao reunir todas essas fisionomias inscritas na longa duração da cultura brasileira, o filme não por acaso permaneceu meses em cartaz. $O$ estudo de Paulo Emílio desses aspectos da cultura brasileira se deve principalmente ao fato de que 0 sucesso dos filmes musicais da Cinédia e de sua fórmula asseguraram "a continuidade do cinema brasileiro durante quase vinte anos: a comédia musical, tanto na modalidade carnavalesca quanto nas outras que ficaram conhecidas sob a denominação genérica de 'chanchadas'" (GOMES, 2016: 159).

Em Pequeno cinema antigo (1969), Paulo Emílio amplifica a importância da "comédia popularesca, vulgar e frequentemente musical" que havia assegurado a plenitude econômica do cinema brasileiro e, ao mesmo tempo, repudiada por mais de 
uma geração de críticos. Ao analisar as comédias musicais como um fenômeno de nossa cultura, Paulo Emílio observa que "uma visão mais aguda permitiria vislumbrar, nessas fitas destinadas aos setores mais modestos da sociedade brasileira, algumas virtualidades que mereceriam estudo e desenvolvimento". O historiador conclui que, apesar de não possuir grande valor artístico ou formal, a chanchada "registrou e exprimiu alguns aspectos e aspirações" do "panorama humano do Rio de Janeiro". É como expressão social que a chanchada possui valor histórico e sociológico, e também psicológico, fato que explica sua persistência no gosto do público com a absorção do entretenimento pela televisão e do seu valor enquanto registro das paisagens naturais e arquitetônicas da vida social da cidade: o gosto pela comédia popularesca, vulgar e musical permanecia como constante no gosto do público, seja do teatro, das revistas, do cinema e, ao final da década de 1960, na preferência dos espectadores de TV (GOMES, 2016: 181).

Assim como o que pode ser dito sobre as reflexões de Paulo Emílio sobre a economia, a cultura laboral e a mentalidade brasileira, marcada pelo subdesenvolvimento, as primeiras aulas do curso Os filmes da cidade (1966) tomadas em conjunto com o Panorama do Cinema Brasileiro (1966) podem ser interpretadas como um esforço de compreender a gênese das comédias musicais e sua expressividade cultural como matriz explicativa para o sucesso comercial do gênero, que garantiu a continuidade produtiva do cinema brasileiro, apesar dos desafios impostos pela presença opressiva de filmes e temas estrangeiros em nossas salas de cinema. Se tivesse redigido e publicado suas anotações sobre o século XIX em conjunto com Panorama (1966), não seria exagero interpretar seu empenho como uma história de longa duração, implicada na investigação de fisionomias fundamentais para explicar aspectos persistentes em nossa história cultural. Por esse e outros motivos, o exercício de reconstituição das expressões artísticas e das fisionomias femininas do Rio de Janeiro ao longo do século XIX é um elo perdido na interpretação história das chanchadas e comédias musicais, tomadas por Paulo Emílio como as produções mais expressivas da cultura cinematográfica brasileira.

\section{Referências}

CABRAL, Mário da Veiga. Corografia do Distrito Federal. Rio de Janeiro: Editora A Noite, 1949.

CRULS, Gastão. Aparência do Rio de Janeiro. Notícia histórica e descritiva da cidade, 02 vol. Rio de Janeiro: José Olympio Editora, 1949. 
FERNANDES, Ana Cândida Franceschini de Avelar. Por uma arte brasileira: Modernismo, Barroco e Abstração Expressiva na crítica de Lourival Gomes Machado. Tese de Doutorado. Escola de Comunicação e Artes (USP), 2012.

FUTEMMA, Olga. Arquivo Paulo Emilio Salles Gomes: rastros de perícia, método e intuição. Dissertação de Mestrado. ECA - Escola de Comunicação e Artes da Universidade de São Paulo, 2006.

GOMES, Paulo Emílio Sales. Anexo G. Cinemateca Brasileira. Coleção Paulo Emílio Sales Gomes. Acesso: PE/PI 0490.

GOMES, Paulo Emílio Sales. Aula de 16 de maio. Cinemateca Brasileira. Coleção Paulo Emílio Sales Gomes. Acesso: PE/PI 0493.

GOMES, Paulo Emílio Sales. Aula de 9 de maio. Cinemateca Brasileira. Coleção Paulo Emílio Sales Gomes. Acesso: PE/PI 0489.

GOMES, Paulo Emílio Sales. Crítica de Cinema no Suplemento Literário, vol. 01. Rio de Janeiro: Paz \& Terra/ Embrafilme, 1982a.

GOMES, Paulo Emílio Sales. Crítica de Cinema no Suplemento Literário, vol. 02. Rio de Janeiro: Paz \& Terra/ Embrafilme, 1982b.

GOMES, Paulo Emílio Sales. Ensino. Inventos e Impulsos. Comentário. Cinemateca Brasileira. Coleção Paulo Emílio Sales Gomes. Acesso: PE/PI 0492.

GOMES, Paulo Emílio Sales. Gastão Cruls. Cinemateca Brasileira. Coleção Paulo Emílio Sales Gomes. Acesso: PE/PI 0495.

GOMES, Paulo Emílio Sales. O cinema brasileiro na década de trinta. Manuscrito. Cinemateca Brasileira. Coleção Paulo Emílio Sales Gomes. Acesso: PE/PI: 0296

GOMES, Paulo Emílio Sales. Uma Situação Colonial? Carlos Augusto Calil (Org.). São Paulo: Companhia das Letras, 2016.

HAMBURGER, Esther; GOMES, Thalles. Leon Hirszman e a trilogia dos Cantos de trabalho. Rumores, n. 21, vol. 11, Jan. -Jun. 2017.

LEITHOLD, Theodor von; RANGO, Ludwig von. O Rio de Janeiro visto por dois prussianos em 1819; Brasiliana, vol 328. São Paulo: Editora Companhia Nacional, 1966.

LUCOOCK, John. Notas sobre o Rio de Janeiro e partes meridionais do Brasil tomadas durante uma estada de dez anos nesse país, de 1808 a 1818. São Paulo: Livraria Martins, 1942.

MACHADO, Antônio de Alcântara. Cavaquinho e Saxofone. Rio de Janeiro: José Olympio, 1940.

MAGALHÃES JÚNIOR, R. Arthur Azevedo e sua época. Rio de Janeiro: Editora Civilização Brasileira, 1966.

MENDES, Adilson Inácio. Trajetória de Paulo Emílio. São Paulo: Ateliê Editorial, 2015. 
MORETTIN, Eduardo; XAVIER, Ismail. La critique cinématographique au Brésil et la question du sous-developpement économique: du cinéma muet aux années 1970. 1895: Révue d'Histoire du Cinéma, Paris, n. 77, hiver 2015.

PEREIRA, Lúcia Miguel. Machado de Assis: Estudo Crítico e Biográfico. São Paulo: Companhia Editora Nacional. Coleção Brasiliana, n. 73, 1936.

PINTO, Pedro Plaza. As tarefas do crítico e os desafios do intelectual, p. 140-167. In:

ALMEIDA, Thiago; XAVIER, Nayara (orgs.) Paulo Emílio: Legado Crítico. São Paulo: CINUSP/ Cinemateca Brasileira, 2017.

SCHLICHTHORST, Carl. O Rio de Janeiro como é (1824-1826). Uma vez e nunca mais. Contribuições de um diário para a história atual, os costumes e especialmente a situação da tropa estrangeira na capital do Brasil. Apresentação, anotações e comentários de Gustavo Barroso. Brasília: Senado Federal, 2000.

SOUZA, Carlos Roberto de. A Cinemateca Brasileira e a Preservação de Filmes no Brasil. Tese de doutorado defendida na ECA- USP.

SOUZA, José Inácio de Melo. Paulo Emílio no Paraíso. São Paulo: Editora Record, 2002. 